\title{
Pengaruh suplementasi taburia (sprinkle) terhadap kadar hemoglobin balita gizi kurang usia 3-5 tahun di kecamatan lewimunding kabupaten majalengka
}

\author{
Teguh Akbar Budiana1, Martha Irene Kartasurya ${ }^{2}$, Judiono ${ }^{3}$
}

\begin{abstract}
Background: Anemia is the most common nutritional problem found in the world, whichal sooccurred in under five children. Anemia is one of themain nutritional problems in Indonesia. Anemia treatment by iron (Fe) supplementation the community level were not successfull yet. This research aimed to investigate the effect of sprinkle supplementation on hemoglobin level of malnourished children aged 3-5 years.

Method: Randomized pretest - posttest control group design was implemented on 66 anemic malnourished children aged 3-5 years. Study was conducted in Lewimunding subdistrict. Subjects were divided into two groups, treatment and control groups. Sprinkle supplementation and nurition education were given to treatment group for 2 months, while control group were only recieved nutrition education. All subjects treated by $400 \mathrm{mg}$ Albendazol before supplementation. Data were nutrient intake collected by 24 hour Recall method. Hb was measured by Cyamethaemoglobin. Data were analyzed by Mann-Whitney, Independent Sample Test, Wilcoxon Signed Ranks, Paired Test and linear regression method.

Result: There was no difference in energy, protein, iron, vitamin B6, vitamin B12 and vitamin C on both treatment and control groups. There is no difference in hemoglobin levels between the groups before supplementation $(p=0.290)$. Hemoglobin increased on treatment group from $(11.14 \pm 0.85 \mathrm{mg} / \mathrm{dl})$ to $(12.31 \pm 0.55 \mathrm{mg} / \mathrm{dl})$ with $\mathrm{p}=0.001$. Hemoglobin also increased from $(10,95 \pm 0,71 \mathrm{mg} / \mathrm{dl})$ to $(11,81 \pm 0,53 \mathrm{mg} / \mathrm{dl})$ in the control group $(p=0.001)$. Sprinkle supplementation increased by hemoglobin level $0.69 \mathrm{mg} / \mathrm{dl}$ higher than the control group $(p=0.001)$. Multivariate analysis that hemoglobin level increased by $0.66 \mathrm{mg} / \mathrm{dl}$ higher compared to the control group after controlled by initial hemoglobin.

Conclusion: Sprinkle supplementation for two months increase hemoglobin level of anemic malnourished children.
\end{abstract}

Keywords: Anemia, sprinkle supplementation, malnourished, children, hemoglobin.

\begin{abstract}
ABSTRAK
Latar belakang : Anemia pada balita merupakan masalah gizi yang paling sering ditemukan di dunia. Anemia merupakan salah satu masalah gizi utama di Indonesia. Penanggulangan anemia dengan suplementasi zat besi (Fe) terbukti kurang maksimal. Penelitian ini bertujuan untuk mengetahui efek pemberian suplementasi taburia terhadap perubahan kadar hemoglobin balita gizi kurang usia 3-5 tahun.

Metode : Desain randomized pretest - posttest control group design dengan subjek penelitian 66 balita gizi kurang yang anemia berumur 3-5 tahun di Kecamatan Lewimunding. Subjek dibagi menjadi dua kelompok, perlakuan dan kontrol. Kelompok perlakuan diberi intervensi taburia dan penyuluhan gizi, sedangkan kelompok kontrol diberi penyuluhan gizi. Sebelum suplementasi seluruh subjek baik perlakuan dan kontrol diberi Albendazol 400 mg. Data asupan zat gizi dikumpulkan dengan metode Recall 24 jam. Hb diukur dengan Cyamethaemoglobin. Suplementasi dilaksanakan selama 2 bulan. Data dianalisis dengan Mann-Whitney, Independent Sample Test, Wilcoxon Signed Ranks, PairedSample Test dan Regresi Linier.

Hasil : Tidak ada perbedaan asupan makanan yang meliputi; energi, protein, besi, vitamin B6, vitamin B12 dan vitamin C antara kelompok perlakuan dan kontrol. Tidak ada perbedaan kadar Hb awal antara kedua kelompok sebelum suplementasi ( $p=0,290)$. Terjadi peningkatan kadar hemoglobin pada kelompok taburia dari 11,14 $\pm 0,85 \mathrm{mg} / \mathrm{dl}$ menjadi 12,31 $\pm 0,55 \mathrm{mg} / \mathrm{dl}$

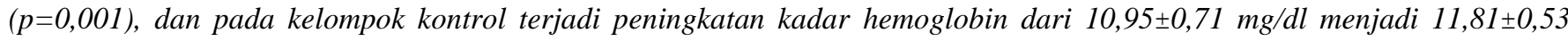
mg/dl (p=0,001). Peningkatan kadar Hb pada kelompok perlakuan lebih tinggi 0,69 mg/dl daripada kelompok kontrol ( $p=0.001)$. Setelah dikontrol oleh kadar Hb awal peningkatan kadar Hb pada kelompok perlakuan 0,66 mg/dl lebih tinggi daripada kelompok kontrol $(p=001)$.
\end{abstract}

Simpulan : Suplementasi taburia meningkatkan kadar Hb balita gizi kurang usia 3-5 tahun.

Kata kunci : Anemia, suplementasi taburia, balita gizi kurang usia 3-5 tahun,kadar hemoglobin

\footnotetext{
1. Sekolah Tinggi Ilmu Kesehatan, Cimahi, (telp : 0226631622 HP. 081320482954 email korespondensi: budianateguh@yahoo.co.id)

2. Departemen Kesehatan Masyarakat, Fakultas Kesehatan Masyarakat, Universitas Diponegoro, Semarang

3. Politeknik Kesehatan Kemenkes, Bandung
}

\section{PENDAHULUAN}

Masalah gizi kurang dan buruk merupakan masalah gizi yang dihadapi oleh Bangsa Indonesia. Hasil Riskesdas tahun 2013, menunjukan jumlah status gizi balita berdasarkan indikator BB/TB yaitu sangat kurus sebesar 5,3\% dan kurus 6,8\%. Kasus 
Jawa Barat pada tahun 2013, balita sangat kurus $0,64 \%$ dan kurus sebesar 6,62\%. Di Kabupaten Majalengka pada tahun 2012 jumlah kasus gizi kurang sebesar 7,2\% dan gizi buruk sebesar 0,67\% . ${ }^{1,2}$

Selain kekurangan asupan zat gizi makro, biasanya balita gizi kurang juga mengalami kurang asupan zat gizi mikro. Akibat defisiensi mikronutrien salah satunya akan menyebabkan anemia. ${ }^{3}$ Anemia merupakan suatu keadaan fisiologis dimana kandungan hemoglobin $(\mathrm{Hb})$ darah lebih rendah dibandingkan normal sebesar $12 \mathrm{mg} / \mathrm{dL}^{4}$

Taburia mengandung 12 macam vitamin dan 4 mineral terdiri dari (vitamin A, vitamin B1, vitamin B2, vitamin B3, vitaminB6, vitamin B12, vitamin D3, vitamin $\mathrm{E}$, vitamin $\mathrm{K}$, vitamin $\mathrm{C}$, asam folat, asam pantotenat, besi, iodium, zink, dan selenium) yang bertujuan membantu tumbuh kembang balita menjadi lebih optimal, meningkatkan daya tahan tubuh, meningkatkan nafsu makan, mencegah anemia dan mencegah kekurangan zat gizi. ${ }^{5}$

Penelitian Muh. Khidri', pada balita 6-24 bulan di Sulawesi selatan menunjukan ada kenaikan kadar Hemoglobin awal dari $10.88 \mathrm{mg} / \mathrm{dl} \pm 1.17 \mathrm{mg} / \mathrm{dl}$ berubah menjadi $11.24 \mathrm{mg} / \mathrm{dl} \pm 1.07$ setelah intervensi taburia $(\mathrm{p}=0.000)$. Perubahan status $\mathrm{Hb}$ awal dan akhir intervensi pada semua sampel menunjukkan bahwa ada peningkatan kadar Hemoglobin sebelum dan sesudah intervensi pada yang menderita anemia, yakni dari $48 \%$ turun menjadi $28 \%$. Penelitian Jahari, A.B ${ }^{7}$, pemberian taburia pada balita berusia 6-59 bulan dari keluarga miskin di Jakarta Utara menunjukan prevalensi anemia ( $\mathrm{Hb}<11 \quad \mathrm{mg} / \mathrm{dl})$ menurun secara bermakna dari $62,3 \%$ pada saat data dasar menjadi $45,5 \%$ pada evaluasi tengah waktu dan menjadi $24,7 \%$ pada evaluasi akhir. Rata-rata kadar hemoglobin balita meningkat dari $10,5 \mathrm{mg} / \mathrm{dl}$ pada data dasar menjadi $11,1 \%$ pada evaluasi tengah waktu dan menjadi $12,0 \mathrm{mg} / \mathrm{dl}$ pada evaluasi akhir. Hasil penelitian ini menunjukkan bahwa pemberian taburia dapat meningkatkan kadar hemoglobin balita.

Untuk mengetahui pemberian taburia sesuai dengan tujuan dan dapat memenuhi kecukupan sasaran maka perlu dilakukan penelitian tentang pengaruh pemberian taburia terhadap $\mathrm{Hb}$ balita umur 3-5 tahun dengan status gizi kurang berdasarkan indeks BB/TB di Kecamatan Lewimunding Kabupaten Majalengka. Pemilihan usia 3-5 tahun dikarenakan pada usia tersebut masih menjadi kelompok yang rentan terhadap masalah gizi di Kecamatan Lewimunding Kabupaten Majalengka.

\section{BAHAN DAN METODE}

Penelitian ini merupakan penelitian eksperiment dengan desain randomized pretest posttest control group design. Penelitian dilakukan terhadap anak balita umur 3-5 tahun yang dibagi menjadi 2 kelompok yaitu kelompok perlakuan yang diberi intervensi taburia (vitamin A, vitamin B1, vitamin B2, vitamin B3, vitaminB6, vitamin B12, vitamin D3, vitamin $\mathrm{E}$, vitamin $\mathrm{K}$, vitamin $\mathrm{C}$, asam folat, asam pantotenat, besi, iodium, zink, dan selenium) dan penyuluhan gizi selama 2 bulan, sedangkan kelompok kontrol hanya diberi penyuluhan gizi. Penyuluhan gizi dilakukan dengan metode konseling.

Subjek penelitian adalah anak balita gizi kurang berdasarkan parameter $(\mathrm{BB} / \mathrm{TB})$ z-score $(\geq-3$ $\mathrm{SD}$ s/d < -2 SD) yang memenuhi kriteria inklusi dan eksklusi. Pemeriksaan awal dilakukan pada seluruh balita yang hadir pada hari pemeriksaan, didapatkan 79 balita anemia (kadar $\mathrm{Hb}<12 \mathrm{~g} / \mathrm{dl}$ ), dari jumlah tersebut dibagi kedalam 2 kelompok dimana pada kelompok perlakuan 39 balita dan kelompok kontrol 40 balita. Namun dalam perjalanan penelitian pada kelompok perlakuan mengalami drop out sebanyak 6 balita dan kelompok kontrol mengalami drop out sebanyak 7 balita (total sampel drop out sebanyak 13 balita), sehingga tinggal 66 balita (perlakuan 33 balita dan kontrol 33 balita) yang memenuhi kriteria sampel. Pengambilan darah dilakukan terhadap 66 sampel dari pre-test sampai post-test. Data yang dikumpulkan terdiri atas keadaan kesehatan, asupan gizi dan kadar hemoglobin. Data riwayat kesehatan yang meliputi lama diare dan episode diare pada balita dikumpulkan dua kali seminggu selama penelitian, data dikumpulkan melalui wawancara dengan orang tua balita. Data asupan zat gizi balita sebelum dan sesudah perlakuan pada kelompok perlakuan dan kontrol diukur dengan metode recall konsumsi $3 \times 24$ jam. Pengambilan darah melalui ujung jari (darah kapiler) yang dilakukan oleh petugas laboratorium, kadar hemoglobin diukur dengan metode Cyanmethemoglobin. Penelitian dilakukan setelah memperoleh dengan Ethical Clearance dari Komisi Etik PenelitianKesehatan (KEPK) FK UNDIP/RSUP dr. Kariadi No. 450/EC/FK/RSDK/2013 tertanggal 01 November 2013.

Untuk menganalisis data asupan zat gizi sebelum dan sesudah pada kelompok perlakuan dan kontrol dilakukan uji Wilcoxon dan Paired Test, sedangkan untuk melihat perbedaan asupan zat gizi kelompok perlakuan dan kontrol digunakan uji Mann Whitney dan Independent Samples Test. Data kesakitan yang meliputi penyakit diare diuji menggunakan Mann Whitney. Perbedaan kadar $\mathrm{Hb}$ awal kelompok perlakuan dan kontrol diuji menggunakan Mann Whitney. Perbedaan perubahan kadar $\mathrm{Hb}$ sebelum dan setelah perlakuan pada kelompok perlakuan dilakukan menggunakan uji Wicoxon Signed Test sedangkan perubahan kadar $\mathrm{Hb}$ sebelum dan setelah pada kelompok kontrol 
menggunakan Paired Test. Perbedaan kadar $\mathrm{Hb}$ antara perlakuan dan kontrol dilakukan menggunakan uji Independent Samples Test. Pengaruh asupan makanan terhadap perubahan kadar $\mathrm{Hb}$ dilakukan dengan menggunakan uji Regresi Linier. Pengambilan kesimpulan terhadaphasil uji hipotesis menggunakan tingkat kepercayaan $95 \%(\alpha=0,05)$ hipotesis nol $(\mathrm{Ho})$ ditolak jika nilai $\mathrm{p}<0,05$.

\section{HASIL}

\section{Tingkat Kecukupan Zat Gizi Balita}

Berdasarkan asupan zat gizi pada tabel 1 , pada kelompok perlakuan dan kelompok kontrol sebelum dan sesudah perlakuan tidak terdapat perbedaan $(\mathrm{p}>0,05)$ hanya asupan vitamin $\mathrm{C}$ pada kelompok kontrol yang terdapat perbedaan $(\mathrm{p}=0,05)$, namun secara deskripsi terdapat peningkatan asupan energi dan protein pada kelompok perlakuan selama perlakuan, sedangkan asupan vitamin B6, vitamin B12, Vitamin C dan Fe pada kelompok kontrol lebih besar dibandingkan pada kelompok perlakuan selama penelitian. Hasil uji beda perbandingan delta asupan zat gizi antara kelompok perlakuan dan kontrol tidak berbeda $(\mathrm{p}>0,05)$.

\section{Kejadian Diare Pada Kelompok Perlakuan dan Kelompok Kontrol}

Kelompok perlakuan ditemukan 5 balita $(9,6 \%)$ mengalami diare, sedangkan pada kelompok kontrol 3 balita $(4,5 \%)$ mengalami diare dengan rata-rata episode diare $>3$ kali dan lama diare 1 - 2 hari. Hasil analisis menunjukan tidak ada perbedaan kejadian diare pada kelompok perlakuan dan kontrol dimana nilai $\mathrm{p}=0,644$.

Tabel 1. Konsumsi Zat Gizi Pada Kelompok Perlakuan dan Kontrol Terhadap \% Kecukupan Gizi Anjuran (KGA) Dalam Umur

\begin{tabular}{|c|c|c|c|c|c|c|c|c|c|c|}
\hline \multirow[t]{2}{*}{ Variabel } & \multirow[b]{2}{*}{$\mathbf{n}$} & \multicolumn{2}{|c|}{ Perlakuan } & \multirow[b]{2}{*}{$\mathbf{p}$} & \multicolumn{2}{|c|}{ Kontrol } & \multirow[b]{2}{*}{$\mathbf{p}$} & \multicolumn{2}{|c|}{$\begin{array}{c}\text { Delta } \\
\text { Konsumsi Zat Gizi }\end{array}$} & \multirow[b]{2}{*}{$\mathbf{P}$} \\
\hline & & $\begin{array}{l}\text { Sebelu } \\
\frac{\mathbf{m}}{X}\end{array}$ & $\begin{array}{c}\text { Sesuda } \\
\frac{\mathbf{h}}{X}\end{array}$ & & $\begin{array}{c}\begin{array}{c}\text { Sebelu } \\
\mathbf{m}\end{array} \\
\end{array}$ & $\begin{array}{c}\text { Sesuda } \\
\frac{\mathbf{h}}{X}\end{array}$ & & Perlakuan & Kontrol & \\
\hline $\begin{array}{c}\text { Energi } \\
\text { (TKE \%) }\end{array}$ & 33 & 89,28 & 94,28 & $\begin{array}{c}0,257 \\
a\end{array}$ & 95,55 & 96,93 & $\begin{array}{c}0,926 \\
a\end{array}$ & 4,99 & 1,39 & $\begin{array}{c}0,670 \\
d\end{array}$ \\
\hline $\begin{array}{l}\text { Protein } \\
(\mathrm{TKP} \%)\end{array}$ & 33 & 106,53 & 113,57 & $\begin{array}{c}0,371 \\
b\end{array}$ & 110,78 & 109,91 & $\begin{array}{c}0,899 \\
b\end{array}$ & 7,04 & $-0,87$ & $\begin{array}{c}0,445 \\
d\end{array}$ \\
\hline $\begin{array}{c}\text { Vit B6 } \\
\text { (TKVit } \\
\text { B6\%) }\end{array}$ & 33 & 91,96 & 101,63 & $\begin{array}{c}0,155 \\
a\end{array}$ & 86,86 & 97,99 & $\begin{array}{c}0,432 \\
a\end{array}$ & 9,67 & 11,13 & $\begin{array}{c}0,910 \\
d\end{array}$ \\
\hline $\begin{array}{l}\text { Vit B12 } \\
\text { (TKVit } \\
\text { B12\%) }\end{array}$ & 33 & 143,09 & 140,36 & $\begin{array}{c}0,701 \\
a\end{array}$ & 133,04 & 157,31 & $\begin{array}{c}0,239 \\
a\end{array}$ & $-2,73$ & 24,24 & $\begin{array}{c}0,243 \\
d\end{array}$ \\
\hline $\begin{array}{c}\text { Vit C } \\
\text { (TKVit } \\
\text { C\%) }\end{array}$ & 33 & 39,81 & 45,94 & $\begin{array}{c}0,456 \\
a\end{array}$ & 37,90 & 54,11 & $\begin{array}{c}0,050 \\
a\end{array}$ & 6,13 & 16,21 & $\begin{array}{c}0,405 \\
c\end{array}$ \\
\hline $\begin{array}{c}\mathrm{Fe} \\
(\mathrm{TKFe} \%)\end{array}$ & 33 & 62,57 & 73,89 & $\underset{a}{0,114}$ & 59,23 & 80,94 & $\begin{array}{c}0,070 \\
a\end{array}$ & 11,32 & 21,71 & $\begin{array}{c}0,913 \\
c\end{array}$ \\
\hline
\end{tabular}

\footnotetext{
a. Wicoxon Signed Ranks test

b. Paired Samples Test

c. Mann Whitney

d. Independent Samples Test
} 
Tabel 2. Kejadian Diare Pada Kelompok Perlakuan dan Kelompok Kontrol

\begin{tabular}{lccc} 
Kejadian Diare & $\mathbf{n}$ & $\begin{array}{c}\text { Median } \\
\text { (minimum-maksimum) }\end{array}$ & p \\
\cline { 2 - 3 } Perlakuan & 33 & $2(1-2)$ & \multirow{2}{*}{$0,644^{*}$} \\
\hline Kontrol & 33 & $2(1-2)$ &
\end{tabular}

*Mann Whitney Test

\section{Perbedaan Kadar Hemoglobin (Hb) Awal Pada Kelompok Perlakuan dan Kelompok Kontrol \\ Pada kelompok perlakuan median $\mathrm{Hb}$ awal} $11,14 \mathrm{mg} / \mathrm{dl}$, sedangkan pada kelompok kontrol median $\mathrm{Hb}$ awal mencapai $11,06 \mathrm{mg} / \mathrm{dl}$. Hasil uji beda menunjukkan tidak terdapat perbedaan antara kadar $\mathrm{Hb}$ awal pada kelompok perlakuan dan kontrol, yang berarti pada awal sebelum penelitian baik pada kelompok perlakuan maupun kelompok kontrol samasama menderita anemi $(\mathrm{p}=0,290)$.

Tabel 3. Perbedaan Kadar Hemoglobin (Hb) Awal Pada Kelompok Perlakuan dan Kelompok Kontrol

\begin{tabular}{lcccc} 
Kadar Awal & $\mathbf{n}$ & $\begin{array}{c}\text { Median } \\
\text { (minimum-maksimum) }\end{array}$ & p \\
\cline { 2 - 3 } Perlakuan & 33 & $11,14(7,71-11,91)$ & $0,290^{*}$ \\
\hline Kontrol & 33 & $11,06(9,01-11,93)$ & \\
\hline
\end{tabular}

*Mann Whitney Test

Perbedaan Kadar Hemoglobin (Hb) Sebelum dan Sesudah Perlakuan Pada Kelompok Taburia

Pada kelompok perlakuan nilai median kadar

$\mathrm{Hb}$ subjek sebelum pemberian taburia sebesar 11,14 $\mathrm{mg} / \mathrm{dl}$ menjadi $12,31 \mathrm{mg} / \mathrm{dl}$. Sebanyak 30 orang atau sebesar $90,9 \%$ pada kelompok perlakuan mengalami peningkatan kadar $\mathrm{Hb}$ sehingga mencapai kadar normal (tidak anemia).

Tabel 4. Kadar Hemoglobin (Hb) Sebelum dan Setelah Suplementasi Pada Kelompok Taburia

\begin{tabular}{lccc} 
Kelompok Taburia & $\mathbf{n}$ & $\begin{array}{c}\text { Median } \\
\text { (minimum-maksimum) }\end{array}$ & p \\
\cline { 1 - 3 } Sebelum & 33 & $11,14(7,71-11,91)$ & $0,001 *$ \\
\hline Sesudah & 33 & $12,31(11,20-13,81)$ & 0 \\
\hline
\end{tabular}

*Wilcoxon singned rank test

Tabel 4 diatas menunjukkan terdapat perbedaan yang signifikan antara kadar $\mathrm{Hb}$ sebelum dan setelah pemberian taburia $(\mathrm{p}=0,001)$. Hasil penelitian ini mendukung hipotesis yang menyatakan bahwa taburia merupakan salah satu multi vitamin yang dikembangkan untuk menanggulangi kekurangan zat gizi mikro pada anak balita terutama anemia. Penelitian yang dilakukan Ziauddin Hyder $d k^{8}$, pada balita 12-24 bulan di Bangladesh yang diberi springkle (besi, vitamin A, asam foat, zinc, vitamin C) selama 2 bulan, menyatakan ada peningkatan yang signifikan pada hemoglobin, serum feritin dan signifikan penurunan serum transferin reseptor $(\mathrm{p}<$ $0,01)$.

Perbedaan Kadar Hemoglobin (Hb) Sebelum dan Sesudah Perlakuan Pada Kelompok Kontrol

Rerata dan standar deviasi kadar $\mathrm{Hb}$ kelompok kontrol sebesar 10,95 $\pm 0,71 \mathrm{mg} / \mathrm{dl}$ menjadi
$11,81 \pm 0,53 \mathrm{mg} / \mathrm{dl}$. Sebanyak 9 orang atau sebesar $27,1 \%$ pada kelompok kontrol mengalami peningkatan kadar $\mathrm{Hb}$ sehingga mencapai kadar normal (tidak anemia). Hasil uji beda menunjukkan terdapat perbedaan yang signifikan antara kadar $\mathrm{Hb}$ sebelum dan setelah pada kelompok kontrol $(\mathrm{p}=0,001)$.

Hasil penelitian ini sejalan dengan hasil penelitian Harisawati ${ }^{9}$ menunjukkan peningkatan rata-rata kadar $\mathrm{Hb}$ ibu hamil sebelum dan sesudah konseling gizi sebesar $0,3 \mathrm{~g} / \mathrm{dl}$ dan memiliki perbedaan peningkatan kadar $\mathrm{Hb}$ yang signifikan dengan kelompok kontrol $(\mathrm{p}=0,001)$. Hasil penelitian Sri $\mathrm{S}^{10} \mathrm{di}$ Pekalongan, pengetahuan responden secara bermakna berhubungan dengan praktek responden dalam pencegahan anemia gizi besi balita di Kota Pekalongan $(\mathrm{p}=0,001)$. 
Tabel 5. Kadar Hemoglobin (Hb) sebelum dan Setelah Pada Kelompok Kontrol

\begin{tabular}{lllll}
\hline Kelompok Kontrol & $\mathbf{N}$ & $\overline{\boldsymbol{X}} \pm \mathbf{S D}$ & $\mathbf{p}$ \\
\cline { 2 - 4 } & Sebelum & 33 & $10,9 \pm 0,71$ & \multirow{2}{*}{$0,001^{*}$} \\
\cline { 2 - 5 } & Sesudah & 33 & $11,8 \pm 0,53$ & \\
\hline * test & & &
\end{tabular}

Perbedaan Kadar Hemoglobin (Hb) Pada melihat delta Hb. Hasil uji statistik menunjukan Kelompok Taburia dan Kelompok Kontrol terdapat perbedaan yang signifikan antara kadar $\mathrm{Hb}$

Untuk mengetahui perbedaan antara kadar $\mathrm{Hb}$ kelompok taburia dan $\mathrm{Hb}$ kelompok kontrol dengan

kelompok taburia dan kontrol $(\mathrm{p}=0,001)$.

Tabel 6. Perbedaan Kadar Hemoglobin (Hb) pada Kelompok Taburia dan Kelompok Kontrol

\begin{tabular}{ccccc}
\hline Peningkatan Kadar Hb & $\mathbf{N}$ & $\bar{X} \pm \mathbf{S D}$ & Lower - Upper & $\mathbf{p}$ \\
\hline Kel. Taburia & 33 & $1,55 \pm 0,98$ & $1,2-1,9$ & $0,001^{*}$
\end{tabular}

*Independent $\overline{t-T e s t}$

Hasil penelitian Titin Hartini ${ }^{11}$ pada balita di Jakarta Utara selama 120 hari, menunjukkan bahwa terdapat perbedaan rata-rata kadar hemoglobin $(\mathrm{Hb})$ yang bermakna antara kelompok balita yang diberi taburia dan yang tidak diberi taburia. Peningkatan kadar $\mathrm{Hb}$ berpengaruh nyata terhadap perubahan prevalensi anemia pada balita, dimana prevalensi anemia pada kelompok balita yang diberikan taburia turun dari $44 \%$ menjadi $21,2 \%$ dan kelompok yang tidak mendapat taburia hanya turun dari $54,7 \%$ menjadi $48,7 \%$.

\section{Pengaruh Suplementasi Terhadap Peningkatan Hemoglobin (Hb) Balita}

Hasil analisis menggunakan GLM (General Linier Model) menunjukkan bahwa kadar $\mathrm{Hb}$ sebelum perlakuan merupakan faktor pengganggu peningkatan Hb balita dengan nilai $(\mathrm{p}=0,001)$.

Tabel 7. Pengaruh Suplementasi Terhadap Peningkatan Kadar Hemoglobin (Hb) Dengan General Linier Model

\begin{tabular}{llccc}
\hline Parameter & B & Std. Error & t & Sig. \\
\hline Intercept & 9.317 & .908 & 10.264 & .000 \\
Hb_pre & -.772 & .083 & -9.356 & .000 \\
[Status=1] & .660 & .127 & 5.192 & .000 \\
[Status=2] & $0^{\mathrm{b}}$ &. &. &. \\
\hline
\end{tabular}

R Squared $=0,649$

Berdasarkan hasil analisis di atas diperoleh angka $\mathrm{R}^{2}$ ( $\mathrm{R}$ Square) sebesar 0,649 atau $(64,9 \%)$. Hal ini menunjukkan bahwa presentase sumbangan pengaruh variabel independen terhadap variabel dependen setelah dikontrol $\mathrm{Hb}$ awal, pemberian suplementasi taburia mampu secara deskriptif meningkatkan kadar $\mathrm{Hb}$ sebesar $64,9 \%$, sedangkan sisanya dipengaruhi variabel lain. Hasil analisis didapatkan model persamaan sebagai berikut:

$\Delta \mathrm{Hb}=9,317+0,66$ (kelompok) - 0,772 (Hb pre)

\section{PEMBAHASAN}

Berdasarkan hasil penelitian ini secara deskripsi terdapat peningkatan asupan zat gizi pada kelompok perlakuan dan kelompok kontrol. Akan tetapi pada kelompok perlakuan peningkatan asupan zat gizi tidak sebesar pada kelompok kontrol, hal ini diduga terdapat pemahaman yang salah pada orang tua balita yang menganggap dengan diberikan suplementasi taburia sudah memenuhi kebutuhan zat gizi balita, padahal suplementasi taburia hanyalah tambahan zat gizi tanpa harus mengurangi asupan zat gizi dari makanan.

Pada penelitian ini perbedaan kadar $\mathrm{Hb}$ akhir kelompok perlakuan dan kelompok kontrol sebesar 0,69 $\mathrm{mg} / \mathrm{dl}$, sedangkan pada penelitian Abdul Salam ${ }^{12}$, perbedaan kadar $\mathrm{Hb}$ adalah $0,43 \mathrm{mg} / \mathrm{dl}$, dan penelitian yang dilakukan M. Khidri ${ }^{6}$ pada balita usia 6-24 bulan di Kabupaten Jeneponto sebesar 0,35 
$\mathrm{mg} / \mathrm{dl}$. Kenaikan kadar $\mathrm{Hb}$ pada penelitian ini berbeda kemungkinan disebabkan komposisi zat gizi mikro yang digunakan berbeda dan lama pemberian yang berbeda. Selain itu subjek dari penelitian juga berbeda dimana pada penelitian ini subjek penelitian adalah balita gizi kurang usia 3-5 tahun sedangkan pada penelitian Abdul Salam ${ }^{12}$ adalah balita usia 12-24 bulan dan pada penelitian Muh. Khidri ${ }^{6}$ adalah balita usia 6-24 bulan. Selain itu pada penelitian ini, yang menjadi subjek penelitian adalah balita yang menderita gizi kurang, sedangkan pada penelitian lain yang menjadi subjek penelitian adalah balita sehat.

Taburia (vitamin A, vitamin B1, vitamin B2, vitamin B3, vitamin B6, vitamin B12, vitamin D3, vitamin $\mathrm{E}$, vitamin $\mathrm{K}$, vitamin $\mathrm{C}$, asam folat, asam pantotenat, besi, iodium, zink, dan selenium) merupakan tambahan multi vitamin dan mineral untuk memenuhi kebutuhan gizi dan tumbuh kembang anak balita. Tujuan pemberian taburia antara lain untuk membantu anak tumbuh kembang secara optimal, meningkatkan daya tahan tubuh, meningkatkan nafsu makan, mencegah anemia dan mencegah kekurangan zat gizi. ${ }^{13}$

Vitamin A berperan dalam memobilisasi cadangan besi di dalam tubuh untuk dapat mensintesis hemoglobin. Status vitamin A yang buruk berhubungan dengan perubahan metabolisme besi pada kasus kekurangan besi. Kekurangan vitamin A dapat menghambat penggunaan kembali cadangan besi yang disimpan dalam hati. Rendahnya status vitamin A akan membuat simpanan besi tidak dapat dimanfaatkan untuk proses eritropoesis. ${ }^{14,15}$ Penelitian Francisca pada anak usia 5-11 tahun di Manado selama 4 bulan, menunjukan terdapat perbedaan peningkatan kadar $\mathrm{Hb}$ pada kelompok yang menerima besi, vitamin A dan seng dibandingkan dengan yang diberikan besi saja $\mathrm{p}<0,001{ }^{16}$

Vitamin B1, B2, B3, dan asam pantotenat merupakan inti metabolisme semua sel, vitaminvitamin tersebut terdapat dalam taburia dan dapat dimanfaatkan dalam metabolisme lemak, protein, karbohidrat dan sangat penting dalam memasok energi untuk meningkatkan nafsu makan sehingga meningkatkan asupan makan. ${ }^{17}$

Vitamin B6 merupakan salah satu vitamin yang paling kompleks dan paling penting dalam metabolisme, vitamin B6 merupakan kofaktor untuk lebih dari 60 enzim yang diketahui banyak diantaranya terjadi di dalam sel dan beberapa diantaranya hanya didapat di dalam hati dan ginjal yang merupakan tempat katabolisme asam amino dan glukoneogenesis. Namun Penelitian Kurniatri di kota Makasar pada wanita usia subur selama 3 bulan menyatakan tidak ada hubungan yang signifikan antara asupan vitamin B6 dengan kejadian anemia dimana nilai $\mathrm{p}=1,00 .{ }^{17,18}$

Asam folat diperlukan dalam berbagai jenis reaksi biokimia. Kekurangan folat menyebabkan kinerja sel menurun, termasuk berperan dalam metabolisme besi yaitu fungsi transferin reseptor. Asam folat juga diperlukan untuk pembentukan sel darah merah dan pendewasaannya dalam sumsum tulang. Selain itu asam folat bersama dengan vitamin B12 dan vitamin B6, berperan penting dalam metabolisme homosistein methionin. Penelitian Mulyawati pada pekerja wanita di Jakarta selama 6 bulan, menyatakan bahwa pemberian suplementasi besi, asam folat dan vitamin $\mathrm{C}$ dapat meningkatkan kadar $\mathrm{Hb}$ sebesar 2,51 g/dl dan kelompok yang diberi besi dan asam folat saja meningkat $2,19 \mathrm{~g} / \mathrm{dl} .{ }^{19}$ Penelitian yang dilakukan oleh Murwakhidah pada pekerja wanita selama 3 bulan di Kabupaten Sokohardjo, menyatakan bahwasannya suplementasi $\mathrm{Fe}$, Asam folat dan vitamin B12 dapat meningkatkan $\mathrm{Hb}$ responden sebesar $2,19 \mathrm{~g} / \mathrm{dl} .^{20}$

Fungsi vitamin $\mathrm{C}$ dalam metabolisme besi (mempercepat absorpsi) di usus dan pemindahannya ke dalam darah. Vitamin $\mathrm{C}$ dapat terlibat dalam mobilisasi simpanan besi terutama hemosiderin dalam limpa. Vitamin $\mathrm{C}$ mempunyai peranan yang sangat penting dalam penyerapan besi terutama dari besi non heme yang banyak ditemukan dalam makanan nabati.

${ }^{17}$ Vitamin $\mathrm{C}$ dapat meningkatkan penyerapan besi non heme sampai empat kali lipat. Hasil penelitian Allenfina pada anak sekolah usia 9-11 tahun di Kecamatan Bunaken Kota Manado, menunjukkan bahwa terdapat hubungan yang signifikan antara asupan vitamin $\mathrm{C}$ dengan kejadian anemia pada anak pra sekolah dengan nilai $\mathrm{p}=0,042 .{ }^{21}$

Zat besi merupakan mikroelemen yang esensial bagi tubuh, yang diperlukan dalam pembentukan darah yaitu untuk mensintesis hemoglobin. Kekurangan zat besi akan menyebabkan terjadinya penurunan kadar feritin yang diikuti dengan penurunan kejenuhan transferin atau peningkatan protoporfirin. Jika keadaan ini terus berlanjut akan terjadi anemia defisiensi besi, dimana kadar hemoglobin turun di bawah nilai normal. Penelitian Cardoso mengenai faktor-faktor yang terkait dengan anemia pada anak-anak di Amazonian, yang menyatakan bahwa salah satu penyebab terjadinya anemia pada anak-anak yaitu kurangnya asupan zat besi yang dikonsumsi. Penelitian lain yang dilakukan Wijaya pada anak usia 6-23 bulan di Kabupaten Aceh Besar menyatakan bahwa subjek yang asupan zat besinya kurang berisiko 1,22 kali menderita anemia dibandingkan dengan subjek yang asupan zat besinya cukup. $^{22,23}$ 
Hasil penelitian ini dapat menunjukan bahwa pada balita gizi kurang yang menderita anemi dengan pemberian suplementasi taburia dan penyuluhan gizi dapat meningkatkan kadar hemoglobin serta dapat menurunkan prevalensi anemia, hal ini dikarenakan adanya peningkatan asupan zat gizi serta adanya interaksi dari vitamin dan mineral yang terdapat pada taburia sehingga mampu meningkatkan penyerapan zat besi. Namun demikian pada kelompok kontrol juga terdapat peningkatan kadar $\mathrm{Hb}$ hal ini dikarenakan adanya pemahaman baru mengenai asupan gizi seimbang sehingga orang tua balita mampu memberikan asupan zat gizi yang baik, hal ini dapat dilihat dari meningkatnya asupan zat gizi setelah peneitian.

\section{SIMPULAN}

1. Asupan zat gizi kelompok perlakuan pada akhir perlakuan lebih rendah dari pada kelompok kontrol, namun demikian pada kelompok perlakuan terdapat peningkatan kadar $\mathrm{Hb}$ pada kelompok yang diberi suplementasi taburia lebih tinggi $0,69 \mathrm{mg} / \mathrm{dl}$ daripada kelompok kontrol $(\mathrm{p}=0,001)$

2. Pada kelompok perlakuan terdapat penurunkan jumlah balita anemia dari 33 balita menjadi 3 setelah diberi suplementasi taburia.

3. Pada kelompok kontrol terdapat penurunan jumlah balita anemia dari 33 balita menjadi 24 balita.

\section{SARAN}

1. Berdasarkan penelitian diatas dari perspektif promosi kesehatan menjadi indikasi yang harus diantisipasi bahwa pemebrian suplementasi yang tidak bijak akan memebawa dampak penurunan pola makan anak, hal ini dikarenakan orang tua kurang memahami arti suplementasi. Selain itu suplementasi merupakan penanggulangan jangka pendek dari permasalahan gizi, akan tetapi penanggulangan jangka panjang harus lebih di perhatikan terkait perubahan perilaku keluarga dalam menyediakan makanan yang mengandung gizi seimbang bagi balita dengan cara pemanfaatan tanaman lokal.

2. Taburia sudah terbukti dapat menurunkan prevalensi anemia pada balita, oleh karena itu program pemberian taburia pada balita hendaknya dilakukan di Kabupaten Majalengka.

\section{DAFTAR PUSTAKA}

1. Puslitbangkes. Laporan Nasional Riset Kesehatan Dasar 2013. Kepkes RI. Jakarta; 2013.
2. Dinas Kesehatan Provinsi Jawa Barat.Profil Kesehatan Kabupaten Majalengka Tahun 2013.Bandung; 2013.

3. Almatsier S, Prinsip Dasar Ilmu Gizi. PT. Gramedia Pustaka Utama. Jakarta; 2009.

4. Miller R. Types of Anemia and Their Causes. http:// kidshealth. org/ parent/ medical/heart/anemia_p3.html. 2002; 20 Februari 2013.

5. Schauer, S Zlotkin. Home fortification with micronutrient sprinkles- A new approach for the prevention and treatment of nutritional anemias. Paediart Child Health. 2003;8(2):87-90

6. Muh. Khidri A, Nursyamsi, A.razak Thaha, Nurhaendar Jafar, Veni Hadju. Efektifitas Taburia Terhadap Kadar Hemoglobindan Ferritin pada balita di kabupaten JenepontoProvinsi Sulawesi Selatan. Media Gizi Masyarakat Indonesia.2013; Vol.2, No.2, Februari :71-77.

7. Jahari, Abas Basuni, Sri Prihatini. Efek program pemberian "Taburia" terhadap kadar hemoglobin balita keluarga miskin di JakartaUtara. Penelitian Gizi dan Makanan. 2009; 32 (1) : 1-8.

8. S. M. Ziauddin Hyder, Farhana Haseen, Mizanur Rahman, Melody C. Tondeur, and Stanley H. Zlotkin. Effect of daily versus once-weekly home fortification with micronutrient Sprinkles on hemoglobin and iron status among young children in rural Bangladesh. Food and Nutrition Bulletin, vol. 28 , no. 2 , The United Nations University; 2007.

9. Harisawati.Konseling Gizi pada Ibu Hamil untuk Perubahan Perilaku Makan dan Status Gizi selama Kehamilan di RSB Pertiwi Makassar (Tesis). Makassar. Universitas Hasanuddin; 2008.

10.Sri S. Pengaruh Interaksi, Pengetahuan Dan Sikap Terhadap Praktek Ibu Dalam Pencegahan Anemia Gizi Besi Balita Di Kota Pekalongan. Tesis Universitas Dipenogoro. Semarang; 2008.

11.Titin Hartini dkk. Kementerian Kesehatan Republik Indonesia, Direktorat Jenderal Bina Gizi dan Kesehatan Ibu dan Anak. Jakarta; 2011. dipublish rabu 20 juli 2011.

12.Abdul Salam, Razak Thaha, Meta Mahendradata. Studi Longitudinal Pemberian Taburin Terhadap PeningkatanKadar $\mathrm{Hb}$ anak usia 12 - 24 bulan di Kabupaten Banggai, Sulawesi Tengah.Media Gizi Masyarakat Indonesia;2011. Vol.1,No.1, 59-64.

13.Ludy. Studi Efikasi Pemberian Sprinkle Taburin Zat Gizi Miro Terhadap Pertumbuhan dan PerkembanganBayi Usia 6-12 Bulan di Kabupaten Baggai, Sulawesi Tengah; 2011.Skripsi tidak diterbitkan. (Online), http://ludydplhk.blogspot.com/2009/09/studi-efikasipemberian sprinkle.html, diakses pada 21 desember 2014. 
14.Gillespie, Stuart. Mayor Issues in the Control of Iron Deficiency the Micronutrien Initiative Unicef, New York, Published by the Micronutrien Initiative Canada; 1998. p.6-74.

15.Kirana Dian Purwitaningtyas.Hubungan Asupan Zat Gizi Dan Pola Menstruasi Dengan Kejadian Anemia Pada Remaja Putri Di Sma N 2 Semarang.Artikel Penelitian. Universitas Diponegoro; 2011.

16.Franciska Louise Kaihatu, Max Mantik. Efektivitas Penambahan Seng dan Vitamin A pada Pengobatan Anemia Defisiensi Besi. Sari Pediatri; 2008. Vol. 10, No. 1, hal 24-25.

17.Parakkasi, A. Biokimia Nutrisi dan Metabolisme (Nutritional Biochemistry and Metabolism karangan asli Linder) Universitas Indonesia, Jakarta; 2010.

18.Kurniati, A.Razak, Nurhaedar Jafar. Hubungan Asupan Zat Gizi Dengan Kejadian Anemia Pada Wanita Prakonsepsi Di Kecamatan Ujung Tanah Dan Kecamatan Biringkanaya Kota Makassar; 2013.

19. Mulyawati Y. Perbandingan Efek Suplementasi Tablet Tambah Darah Dengan dan Tanpa Vitamin C Terhadap Kadar Hemoglobin Pekerja Wanita di
Perusahaan Plywood Jakarta, Universitas Indonesia. Thesis; 2003.

20.Muwakhidah. Efek suplementasi fe, asam folat dan vitamin b 12terhadap peningkatan kadar hemoglobin (hb)pada pekerja wanita(di Kabupaten Sukoharjo.Jurnal Penelitian Sains \& Teknologi, Vol. 11, No. 1, April 16 2010; 11 - 18.

21.Allenfina O. Tadete, Nancy. S.H. Malonda, Anita Basuki. Hubungan Antara Asupan Besi, Protein dan Vitamin C dengan Kejadian Anemia pada Anak Sekolah Dasar Di Kelurahan Bunaken Kecamatan Bunaken Kepulauan Kota Manado. Fakultas Kesehatan Masyarakat Universitas Sam Ratulangi Manado; 2013. 1-7.

22.Cardoso, M Scopel, K Muniz, P Villamor, E Ferreira.Underlying Factors Associated with Anemia in Amazonian Children: A PopulationBased, Cross Sectional Study. Plos One; 2012. 7 (5), pp. e36341.

23.Wijaya, C. Hubungan Asupan Zat Gizi dengan Kejadian Anemia pada Anak Usia 6-23 Bulan di Kabupaten Aceh Besar. Tesis. Fakultas Kesehatan Masyarakat Program Studi Magister Epidemiologi. Depok; 2011. 